\title{
DESCRIÇÃO DO ALÓTIPO DE SIMULIUM PRUINOSUM LUTZ, 1910 E CARACTERES ADICIONAIS DA FÊMEA *
}

\author{
MARIA APARECIDA VULCANO \\ Departamento de Zoologia, Secretaria de Agricultura, São Paulo
}

(Com 10 estampas)

O Senhor Diretor do Departamento de Zoologia incumbiu-me de atender à solicitação do Club Indiano, cuja séde se situa às margens da Reprêsa Guarapiranga, próximo da cidade de S. Paulo, no sentido de estudar um modo de combater a ação importuna dos borrachudos que se criam nas águas ali reunidas e constituem um verdadeiro flagelo aos associados daquela agremiação esportiva. A referida reprêsa é abastecida pelo rio Guarapiranga e formada por uma barragem de $1,5 \mathrm{~km}$ de comprimento por $18 \mathrm{~m}$ de altura máxima; sua capacidade de armazenamento é de 200 milhões de metros cúbicos. Existem na barragem três canais: o primeiro é o que alimenta a nova Casa de Bomba do Departamento de Àguas e Esgotos; o segundo alimenta a Usina Elevatória de Pedreiras de onde a água é recalcada para a Reprêsa Billings (também chamado canal de descarga do Guarapiranga); o terceiro alimenta a antiga Casa de Bomba que recalca a água para o alto da Boa Vista.

Com o auxílio de um barco explorei tôda a região da reprêsa, circunvizinha ao Clube, conseguindo capturar numerosos adultos de S. pruinosum Lutz, 1910.

Posteriormente, para melhores investigações, voltei ao Clube Indiano, detendo-me no exame da comporta da Light e dos tanques de decantação de água, com a qual o D.A.E., abastece esta cidade. Consegui, então, localizar dois grandes focos de criação dêsse importuno inseto, um no canal de descarga onde a velocidade da água atinge $3 \mathrm{~m}$ por segundo, por isso com alto grau de oxigenação (Est. 1, fot. 1 e 3): outro nas paredes dos tanques onde, numa extensão de muitos metros de comprimento, encontram-se enormes colônias de pupas e larvas em número verdadeiramente alarmante (Est. 1, fot. 5 e 6).

* Recebido para publicação a 13 de novembro de 1958.

Trabalho realizado no Departamento de Zoologia da Secretaria da Agricultura de S. Paulo, sob os auspícios do Conselho Nacional de Pesquisas. 
Essa concentração de pupas, forrando quase que totalmente as paredes dos tanques de decantação, não oferecia facilidades para o recolhimento de amostras a serem estudadas no laboratório. Na raspagem das paredes as pupas eram destruidas e, como o trabalho se fazia sob um lençol dágua que deslisava sôbre tais superfícies, muitas se perdiam.

Posteriormente, com a colaboração do D.A.E., e com o inestimável auxílio do Sr. Carlos Barbosa, diretor da praça de desportos daquele Clube, conseguiu-se trabalhar com mais eficiència e proveito.

Dada a grande aglomeração de ovos, larvas e pupas naquelas paredes e, conseqüentemente de adultos, fomos obrigados a tomar medidas rápidas e drásticas para extermínio dessa praga. Assim é que, depois de usados lança-chamas, procedemos à limpeza das referidas paredes com fortes escôvas de aço, deixando-as completamente livres dêsses insetos. Futuramente processos de engenharia sanitária deverão ser tentados naqueles tanques, dada a impossibilidade de se usar substâncias tóxicas que, impedindo a vida aquática dos borrachudos, contaminariam a água que é utilizada para o abastecimento da cidade.

O segundo foco de pupas e larvas, sem dúvida o de acesso mais difícil pela sua localização, foi o da comporta da Light. Todavia, o inestimável auxílio que recebi do Sr. Superintendente da Light, Dr. W. M. Lutz, homem de ampla visão, sempre pronto a ajudar os cientistas e extremamente interessado em solucionar êsses graves problemas, facilitou sobremaneira o meu trabalho.

Para o nosso trabalho nesse local era imprescindível, em primeiro lugar, fechar quase totalmente a comporta para limpeza do canal de descarga (Est. 1, fot. 2); em segundo lugar, calafetar as paredes de táboas que separam os canais 1 e 2, isto é, o de fornecimento de água ao D.A.E., e o de descarga ao antigo Rio Pinheiros. Nas frinchas, entre as táboas, por onde escoavam pequenas porções de água, denominada "água chorada", encontramos um verdadeiro turbilhão de fêmeas a desovar, bem como um alto índice de larvas, em todos os seus estádios (Est. 1, fot. 2) . As pupas eram aí muito raras, o que não acontecia mais adiante, nas paredes do canal, onde havia grande número delas.

Para calafetar os canais usou-se escória de carvão mineral. Em seguida, o leito e as paredes que estavam em contato com a água, foram intensivamente escovados e lavados com creolina pura a fim de eliminar as larvas não atingidas pela escôva de aço.

Quero consignar aqui os meus sinceros agradecimeritos a todo corpo técnico da Light $e$, em particular, ao Dr. Lutz que nos deu decisivo apoio. Agradeço também ao Sr. Giro Pastore, Fotógrafo do Departamento de Zoologia, as magnificas fotografias que ilustram êste trabalho; ao $\mathrm{Sr}$. Sebastiāo Medeiros o meu reconhecimento ao auxílio que me tem prestado na coleta e criação do material.

Entre as numerosas fêmeas apanhadas com isca humana em São Carlos, Usina Monjolinho, foco de Pênfigo Foliáceo, uma carregava em seu abdômen ovos de Dermatobia, fato êste ainda não constatado na literatura. 
Com a finalidade de melhor caracterizar as espécies de Simuliidae que LUTz descreveu no princípio dêste século, elaborei o presente trabalho que tratará do Simulium pruinosum.

Como a fêmea desta espécie já foi suficientemente estudada por LUTz, limitar-me-ei a descrever dêste sexo tão sòmente as peças que estão montadas em lâminas.

O seu alótipo, entretanto, é aqui minuciosamente descrito. Como as minhas observações sôbre esta espécie se basearam em cêrca de 362 espécimes, assinalarei as variações encontradas, quer nos adultos como nas pupas e larvas.

\section{Simulium pruinosum Lutz, 1910}

Simulium pruinosum Lutz, 1910, Mem. Inst. Oswaldo Cruz, 2:250, 263, 265, 266 figs. 22-23, 38, 40-41

Simulium pruinosum Surcouf-Rincones, 1911, Essai Dipt. Vuln. Venez., 1:283

Melusina pruinosa Gedoelst, 1911. Synop. Parasit.: 212

Simulium pruinosum Patton \& Cragg, 1913, Textbcok Med. Entom.: 170

Simulium pruinosum Lutz \& Machado, 1915, Mem. Inst. Oswaldo Cruz, 7:46

Simulium pruinosum Neiva, 1916, Mem. Inst. Osivaldo Cruz, 8:93-97

Simulium pruinosum Wilhelmi, 1920, Kriebelmueckenplage: 77, 123, 241

Simulium pruinosum Lutz, 1922, Fol. Med.. 3:90-91

Simulium pruinosum Pinto, 1930, Trat. Parasit.: 477, 481

Simulium pruinosum Pinto, 1931, 7.a Reun. Soc. Arg. Pat. Reg. Norte: 704, 708, 725, 756, figs. 31

Simulium pruinosum Pinto, 1938, Zoo-Parasit. Med. Vet.: 139, pl. 48, fig. 8

Eusimulium pruinosum Lane \& Porto, 1939, Bol. Biol., 4:169, 174, figs. 5-7

Eusimulium pruinosum Lane \& Vulcano, 1943, Rev. Entom., 14:436, figs. $10-12$

Simulium pruinosum Smart, 1945, Trans. R. Ent. Soc. Lond., 95:511

Simulium pruinosum Vargas, 1945, Inst. Sal. Enf. Trop. Mex. Monogr. 1:186

Simulium (Grenieriella) pruinosum Vargas \& Najera, 1951, Rev. Soc. Mex. Hist. Nat. 12:143, fig. 76, 77

Simulium pruinosum Briceño-Iragorry \& Iriarte, 1946, Bol. Lab. Clin. Luis Razetti, 15:464

Simulium pruinosum Briceño-Iragorry \& Ortiz, 1957, Bol. Ven. Lab. Clin., 2:41-42, 44, 45

Simulium (Eusimulium) pruinosum Floch \& Abonnec, 1946, Inst. Pasteur Guyane et Terr. Inini., Publ. 136:8

Criando em laboratório cêrca de 362 exemplares, dos quais 179 eram of of e 183 $q$ \& , pude montar em lâminas uma série de $ㅇ$, $\hat{\delta} \hat{b}$, pupas e larvas e constatar as principais variações da armadura bucal, da pinça ou da altura e número cie dicotomização das 
brânquias. Para melhor reconhecimento de tôdas essas variações desenhei-as minuciosamente. Os exemplares $q$ que examinei são um pouco maiores: LuTz assinalou $3 \mathrm{~mm}$ e eu encontro medidas que vão de 3 a $4,5 \mathrm{~mm}$, medidas essas tomadas em exemplares vivos.

Área ocular frontal (Est. 2, fig. 1) pequena. Antena (Est. 2, fig. 2) com 11 artículos; cerdas pretas no ápice do I e II, sendo os restantes recobertos de pequenas cerdas. Palpo maxilar (Est. 2, fig. 3) com 5 artículos, os três primeiros esclerosados e com longas cerdas; no III artículo nota-se o órgão sensorial de LUTz, normal; o IV e o V recobertos de pequenas cerdas dispostas em círculos por todo o segmento. Mandíbula (Est. 2, fig. 4) com a borda exteina lisa ou com 1 a 3 dentes (Est. 2, figs. 5 e 6); a borda interna apresentando de 25 a 27 dentes agudos encurvados para dentro. Maxila (Est. 2, fig. 7) em forma de $\mathrm{V}$ na extremidade distal; no lado interno com 8 a 12 dentes retrovertidos e ponteagudos; no lado externo com 15 a 18 dentes encurvados para cima e para dentro. Labro-epifaringe (Est. 2, fig. 8) com duas zonas de esclerose e apresentando no ápice dois grupos de 3 dentes fortes, bem esclerosados, voltados para cima e para trás, e nas partes laterais do labro observam-se ainda alguns espinhos longos e não esclerosados. Hipofaringe (Est. 2, figs. 9 a 13) apresentando a armadura bucal com os processos laterais bem espandidos e esclerosados; o espaço mediano apresentando dentes grossos, curtos e irregulares distribuidos na porção mediana e uma fileira de dentes pequenos com aspecto de serrilha que alcançam as expansões laterais; extremidade apical (Est. 2, fig. 14) de aspecto normal. Lábio (Est. 2, fig. 15) curto; teca quadrangular com algumas cerdas longas na porção mediana; labelo I curto com a faixa transversal esclerosada, com cerdas curtas e longas entremeadas e apresentando uma grande expansão hialina, no lado interno, a qual é munida de cerdas curtas, espiniformes, implantadas em tubérculos; labelo II pequeno, arredondado e com grande número de cerdas bem desenvolvidas; lígula grande.

Asas (Est. 3, fig. 16) - Com 3,5 $\mathrm{mm}$ de comprimento e $1,8 \mathrm{~mm}$ de largura máxima. A C com numerosas cerdas espiniformes em mistura com outras mais finas, sendo as da base as de maior comprimento; Sc com uma fileira de cerdas; seção basal de $\mathbf{R}$ com cerdas finas; $\mathbf{R}_{1}$ com cerdas espiniformes entremeadas com algumas cerdas finas; Rs com uma fileira de cerdas finas.

Pernas - Já descritas por Lutz e agora figuradas (Est. 3, figs. 17, $18,19)$; calcípala pouco desenvolvida; pedisulco bem desenvolvido, ambos na Est. 3, fig. 20. Garras (Est.3 fig. 21) bem desenvolvidas, esclerosadas e com um dente basal conspícuo.

Abdômen - Urômero I prêto fôsco com duas manchas ovais nos lados, prêto-aveludadas, e com a franja de pêlos amarelos e pretos nas margens, sendo tais pêlos mais longos e em maior número nos lados. Urômero II com uma mancha central nacarada muito intensa, encontrando-se ao lado dessa mancha duas outras triangulares de côr prêto-aveludada. Urômero III a V com placas grandes de côr prêto-fosca 
e de formato triangular. Urômeros V a VIII com placas prêto-fôscas, ocupando quase tôda a superfície dorsal. Não há placas esternais.

Terminalia - Gonapófises anteriores (Est. 3, fig. 22) bem desenvolvidas e pouco esclerosadas, com poucas cerdas; expansões das gonapófises salientes, arredondadas, hialinas e com muitas cerdas curtas. Parapróctos (Est. 3 fig. 23) muito grandes, chegando mesmo a cruzar-se com a do outro lado; saliência ventral com uma porção mediana esclerosada e a porção apical hialina, sendo esta recoberta de curtas cerdas e espinhos delgados. Cercas (Est. 3, fig. 23) semicirculares e recobertas de finas cerdas. Forquilha genital (Est. 3, fig. 24) com a haste relativamente curta e com zonas irregulares de esclerose; expansões com uma saliência esclerosada na parte superior.

o - Comprimento do corpo $4 \mathrm{~mm}$; coloração geral castanha aveludada.

Cabeça - Fronto-clípeo pequeno, triangular, prêto e densamente recoberto de pruina prateada e com longas cerdas negras em mistura com cerdas doiradas. Vertex e occiput reduzido, pela juxtaposição dos olhos, ficando tão sòmente uma estreita faixa, na qual se implantam uma fileira de cerdas negras. Olhos grandes, sendo os $3 / 4$ superiores de omatídios grandes e de côr vermelho-alaranjada; o $1 / 4$ inferior de omatídios pequenos e de côr vermelho-escura. Antenas (Est. 4, figs. 25 e 26) com 11 artículos, castanho-escuros, sendo os artículos I, II e a metade basal do III, ocráceos, com cerdas longas e pretas; os artículos restantes apresentam cerdas curtas e esbranquiçadas. O tamanho e a configuração da antena variam um pouco como se depreende das figuras. Palpos maxilares (Est. 4, fig. 27) castanho-escuros e recobertos por cerdas negras entremeadas com algumas amarelas. Peças bucais castanho-claras com ligeiro escurecimento e algumas cerdas negras. Maxila (Est. 4, fig. 28) pouco desenvolvida, hialina, tendo na extremidade e no lado interno da porção basal espinhos hialinos. Mandíbula (Est. 4, fig. 29) muito atrofiada, delgada, hialina, com uma fraca zona de esclerose ao redor da depressão de Jobling e com pequenos espinhos na extremidade apical, sòmente visíveis quando a peça é corada. Labro-epifaringe (Est. 4, fig. 30) com a extremidade apical recoberta de longas cerdas, destacando-se as da porção mediana que formam um aglomerado mais compacto; logo atrás dêsse aglomerado nota-se uma pequena placa com 3 a 4 curtas cerdas. Hipofaringe (Est. 4, fig. 31) com a extremidade distal afilada, tendo na borda espinhos longos, finos e hialinos; armadura bucal (Est. 4, fig. 32) inerme e quase totalmente hialina. Lábio (Est. 4, fig. 33) com a teca subquadrangular, havendo aí, raras cerdas; labelo I com algumas cerdas e faixa diagonal esclerosada; no lado interno com algumas cerdas espiniformes implantadas em tubérculos; labelo II com as cerdas longas; lígula desenvolvida.

Tórax - Calos umerais castanhos, com pruina alvacenta e densamente revestidos de escamas doiradas, em mistura com raros pêlos, pretos. Escudo com a côr castanha predominante, mas modificando-se 
a incidência luminosa nota-se, por trás, um desenho escuro formado por 3 faixas estreitas que se fundem em uma grande mancha na frente do escutelo, duas faixas pretas recobrem as margens laterais. Com incidência luminosa diferente o escudo apresenta-se inteiramente recoberto por uma intensa pruina nacarada; visto de frente esta pruina se restringe apenas a duas manchas centrais, triangulares, situadas logo atrás dos olhos e a uma larga faixa castanho-escura, que tem no meio uma linha preta. Quando a luz incide sôbre o inseto por cima, os desenhos pretos do escudo tornam-se pouco perceptíveis, realçando-se então a côr do fundo, que é castanho-aveludada, e o seu revestimento que é formado de curtas e esparsas escamas de côr amarela com reflexos acobreados. Neste particular as $q$ q contrastam com os $\hat{b} b$, pois apresentam escamas de côr prateada, arrumadas em pequenos feixes. Escutelo castanho aveludado, com pequena mancha preta-aveludada, mediana e apical, recoberto por escamas transversais côr de ouro-velho, cerdas marginais negras. Pós-noto castanho, com manchas pretas, total e densamente recoberto de pruina com reflexos prateados. Pleuras castanhas, com manchas irregulares pretas e recobertas por pruina nacarada; tufo de pêlos pretos em mistura com amarelos encontram-se nos mesoepímeros e pós-parápteros.

Asas - Com 2,5 mm de comprimento por $1,4 \mathrm{~mm}$ de maior largura, hialinas, iridescentes, apresentando a mesma distribuição de cerdas e pêlos encontradas nas $q \circ$, porém em número bem reduzido.

Halteres - Com o pedúnculo escuro, recobertos de pruina e longos pêlos pretos; capítulo amarelo.

Pernas - Par anterior: Coxa amarela com pêlos amarelos e alguns pretos. Trocânteres também claros, com pequena porção apical infuscada e com cerdas claras e algumas pretas. Fêmur com a face externa amarela e recoberta de cerdas amarelas e pêlos pretos; face interna escura com pêlos pretos que são mais longos na margem. Tíbias e tarsos pretos densamente recobertos de cerdas pretas. Par médio: Coxa ocrácea, com cerdas pretas. Trocânteres claros, com cerdas claras e algumas pretas. Fêmur amarelo, com o ápice infuscado, recoberto por escamas amarelas e raros pêlos pretos. Tíbias pretas, com pequena porção basal ocrácea e densamente revestidas de escamas e pêlos pretos, havendo no ápice um par de esporões recobertos por curtas e finas cerdas. Tarsômero I com os $3 / 4$ superiores amarelos, com pruina branca e escamas amarelas; o $1 / 4$ inferior prêto, com cerdas pretas. Tarsômeros II a V pretos e revestidos com cerdas da mesma côr. Tarsômeros I a III com dupla fileira de cerdas espiniformes e um pequeno esporão no ápice de cada artículo. Par posterior: Coxa ocrácea, com cerdas pretas e amarelas. Trocânter amarelo com raras cerdas curtas e pretas. Fêmur com a face externa amarela, densamente recoberta de cerdas amarelas e algumas pretas e com o ápice prêto, recoberto de cerdas da mesma côr; a face interna é escura com cerdas pretas e com longos pêlos pretos na base. Tíbia na metade basal amarela com cerdas também amarelas, sendo o restante prêto, com cerdas pretas e 
longas cerdas negras na base. Tarsômeros I e II com pequena porção apical preta e cerdas da mesma côr, sendo a porção basal amarela revestida totalmente de pêlos amarelos. Os tarsômeros restantes pretos com cerdas pretas. Pedisulco bem desenvolvido, porém menor que o da $q$. No tarsômero I existe uma fileira de cerdas e dentes juxtapostos, curtos e com aspecto de uma serrilha e também uma dupla fileira de cerdas espiniformes; nos tarsômeros I a IV encontram-se um esporão no ápice.

Abdômen - Prêto aveludado. Segmento I com uma franja de longos pêlos amarelos e alguns pêlos curtos e pretos na borda posterior. O II é prêto-aveludado, com grande mancha prateada lateral. O III completamente prêto nos lados. Do IV ao VIII há manchas irregulares de pruina nacarada, cerdas pequenas, esparsa por todos os segmentos. Placas tergais quadrangulares; placas esternais medianas do III ao VIII quase iguais em tamanho e com pequenas cerdas na porção mediana.

Terminália - Pinças (Est. 4, figs. 34 a 46) com o lóbulo basal mais ou menos quadrangular e com cerdas esparsas; lóbo apical com uma vez e meia o comprimento do basal, cônico e com o ápice encurvado e munido de cerdas que podem variar em número, tamanho e disposição (Est. 4, figs. 35 a 46). Falosoma com o processo anterior, em vista ventral, largo, curto e ligeiramente arqueado, havendo na porção mediana apical, espinhos delgados, não esclerosados; no ângulo inferior com duas projeções dirigidas para baixo e bem esclerosadas. Processo posterior do falósoma (Est. 4, fig. 48) formado lateralmente por uma membrana irregular esclerosada, sendo o restante hialino e finamente espiculoso. Tergito $\mathrm{X}$ subquadrangular e esclerosado. Cercas hialinas e recobertas por finas cerdas entremeadas com algumas mais longas.

Pupa - As pupas acham-se reunidas em grande número, formando espessos aglomerados, tendo-se dêles uma pálida idéia na Est. 5, fig. 50. Casulo (Est. 6, fig. 51) de forma cônica, em vista lateral o seu eixo longitudinal forma um ângulo devido a uma projeção irregular que completa a abertura do casulo. Este é formado por um tecido que apresenta um aspecto grosseiro na superfície dorsal e frouxo na superfície de fixação, aspecto diferente dêste mesmo tecido, se encontra na projeção que completa a abertura circular que é bastante espêssa em sua borda. Pele pupal cefálica (Est. 6, fig. 52) com um par de tricomas bífidas ou quadrífidas entre o estôjo das antenas e mais dois pares de cerdas simples nos lados; Zonas irregulares existem próximo ao estojo das antenas e na região que recobre o vertex do imago. Pele torácica com apenas uma tricoma quadri ou multipli-ramificada (Est. 6, fig. 53); logo abaixo da inserção das brânquias respiratórias há algumas cerdas (Est. 6, fig. 54) simples ou bifidas esparsas. Brânquias respiratórias: em cêrca de 50 montagens constatou-se poderem elas variar em número, tamanho e altura de dicotomização, em exem- 
plares diferentes ou num mesmo exemplar, de um lado para o outro. Assinalamos, assim, as possibilidades de 12 combinações, sendo que a mais constante foi a de 20 brânquias para cada lado. Assim é que em uma amostra apanhada ao acaso, dentre as 5 capturas que fiz, en. contrei as seguintes variações:

\begin{tabular}{|c|c|c|c|c|c|c|c|c|}
\hline 1 & ex. & $\mathrm{com}$ & 17 & br & $\mathrm{D}$ & e & 16 & br \\
\hline 1 & " & " & 17 & "' & "' & $"$ & 17 & " \\
\hline 1 & " & " & 19 & $"$ & $"$ & "' & 16 & " \\
\hline 1 & "' & " & 21 & $"$ & $"$ & $"$ & 18 & " \\
\hline 1 & " & " & 21 & $"$ & "' & $"$ & 19 & ", \\
\hline 2 & "' & "' & 19 & $"$ & $"$ & "' & 19 & " \\
\hline 3 & " & "' & 18 & " & $"$ & $"$ & 17 & "' \\
\hline 3 & $"$ & " & 18 & $"$ & "' & $"$ & 18 & $"$ \\
\hline 3 & $"$ & "' & 20 & $"$ & $"$ & $"$ & 18 & " \\
\hline 4 & "' & " & 20 & $"$ & "' & $"$ & 19 & ", \\
\hline G & " & "' & 19 & $"$ & " & $"$ & 18 & " \\
\hline 12 & "' & "' & 20 & $"$ & $"$ & $"$ & 20 & ", \\
\hline
\end{tabular}

As brânquias são curtas, mas bem visíveis na abertura do casulo devido o dorso da pupa manter-se em parte exposto (Est. 5, fig. 50) . Os ramos originam-se de 4 troncos que, para melhor contagem, foram dissecados e esquematicamente ilustrados (Est. 6, fig. 55). O ramo anterior que, um pouco distante da sua base, dá origem a outros dois ramos secundários, quase não sofre variações. O ramo médio externo que dá origem a dois ramos secundários, sofre variações na altura da bifurcação (Est. 6, figs. 56 e 57), no comprimento e no número de brânquias; em um exemplar (Est. 6, fig. 59) pude constatar uma pequena projeção, mas em outro encontrei uma verdadeira dicotomização (Est. 6, fig. 60). Com forte aumento as brânquias mostram uma estrutura de finas espículas, dispostas em círculos e com uma terminação com as mais variáveis formas (Est. 6, fig. 61). O ramo médio interno apresenta, em geral, 8 ramos secundários e uma variabilidade muito grande no número de ramificações (de 5 a 8) na sua altura, na sua posição, nos pequenos entumecimentos ou processos apendiculares que gradativamente aumentam de tamanho, tornando difícil saber se se trata de uma verdadeira brânquia. Tais variações podem encontrar-se num mesmo indivíduo. Figuramos tôdas as possíveis variações (Ests. 7 e 8) para que assim se tenha uma idéia objetiva das mesmas. No ramo posterior, que em média apresenta 8 galhos, também se constatou variação no número de ramos (de 6 a 8 ) e na sua altura de dicotomização (Est. 9) . Pele abdominal com o gancho da extremidade distal muito pequeno.

Larva - Comprimento da larva em último estádio, $10 \mathrm{~mm}$. Vivendo em grandes colônias com larvas de $S$. orbitale Lutz, 1910, estas prontamente se diferenciam por apresentar o corpo coberto de escamas, 
sendo as larvas de $S$. pruinosum completamente lisas (fig. 50) e com manchas esverdeadas.

Cabeça - Antena (Est. 10, fig. 110) com 3 segmentos: no I, irregularmente esclerosado, observa-se em seu ápice um par de espinhos grossos e hialinos. Escôva cefálica (Est. 10, fig. 111) com um grande tufo de cerdas grossas e pectinadas e na porção basal com um pequeno tufo de cerdas, também com pectinação. Mandíbula (Est. 10, fig. 112) com cerdosidade longa medianamente, no ápice com duas grandes cerdas rijas esclerosadas; no ângulo súpero-interno há um grupo de dentes (Est. 10, fig. 113) bem esclerosados, sendo o dente mediano o maior e ladeado por 3 menores, abaixo dêstes encontram-se outros 4 dentes ponteagudos e, ao nível do último, mas do lado interno, uma fileira de mais 7 dentes ponteagudos, largos e hialinos, que completam uma fileira de 16 dentes; na base existe uma fileira de cerdas, cujo ápice se divide em várias pontas; acima desta fileira há um tufo de cerdas finas e longas, em mistura com cerdas diferenciadas. Palpo maxilar (Est. 10, fig. 114) cônico, alongado, esclerosado com esparsa pilosidade e tendo no ápice espinhos curtos não esclerosados. Maxila (Est. 10, fig. 114) arredondada, com diversos tufos de pêlos diferenciados; no ápice com uma grande cerda hialina, na base da qual há uma curta cerda espiniforme. Mento (Est. 10, fig. 115) tendo na borda superior dentes bem esclerosados, sendo um grande, mediano, que é ladeado por 3 ou 4 outros, pequenos e dois externos ponteagudos, perfazendo um total de 9 a 10 dentes (Est. 10, fig. 116); as bordas laterais, em continuação ao dente externo com uma serrilha de dentes pequenos e hialinos; junto a estas bordas há também uma fileira de 5 a 7 cerdas grandes, erectas e bem esclerosadas.

Tórax - Pseudópodo com o disco armado de numerosas fileiras de ganchos.

Abdômen - Disco posterior armado de diversas fileiras de ganchos. Armadura anal formada por uma forte barra de esclerose. Brânquias anais (Est. 10, fig. 117) com 3 ramos multiramificados.

Tipos - Lectótipo o número 141, selecionado do material da Coleção Lutz, do Instituto Oswaldo Cruz. Alótipo ô, bem como a série de + o e $\hat{o}$ of de pupa e larva que serviu para o estudo, na coleção do Departamento de Zoologia da Secretaria da Agricultura.

\section{Lassance.}

Localidade tipo - Minas Gerais, Rio das Velhas, perto de

Distribuição geográfica - BRASIL: Minas Gerais, Cachoeira do Brejinho, Lutz \& Machado col., 1915, \&; Belo Horizonte, Capela Nova do Betim, Lutz col., 1922, ๆ. Goiás: entre Duro e Pôrto Nacional, Neiva col., 1916, ; Jaraguá, Frei Miguel col., 1944, \&. Mato Grosso: Rio das Mortes, Adrian Bueno de Oliveira col., 1937, ․ . S. Paulo: Rio Paraná, Pôrto S. Pedro, d'Andretta col., 1944, \&; Pôrto Baunilhas, 
$330 \mathrm{~km}$ de Pres. Epitácio, d'Andretta col., 1944, ؟; Pôrto Cabral, Travassos $F^{0}$ col., 1941, q $q$; S. Carlos, Usina Monjolinho (foco de Pênfigo Foliáceo), Vulcano \& Lane col., 1944, q \&; Boracéia, Travassos Fo col., 1946, \&; S. Paulo, S. Bernardo, Chácara Tacase, Vulcano, Werner \& Medeiros col., VII-1956, ㅇ o; S. Paulo, Sto. Amaro, Reprêsa do Guarapiranga, Vulcano col., maio, junho, julho, agôsto e setembro de 1958, + , ô, pupa e larva. ParaguaI: Rio Paraná, entre Foz de Iguaçu e Pôrto Pres. Franco, d'Andretta col., 1944.

\section{REFERÊNCIAS BIBLIOGRÁFICAS}

Briceño-Iragorry, L. \& Iriarte, D.R., 1946, La Familia Simuliidae en Venezuela. Bol. Lab. Clin. Luis Razetti, 15: 401-479.

Briceño-Iragorry, L. \& Ortiz, I., 1957, Los Simulidos de Venezuela. Bol. Ven. Lab. Clin., 2:23-57.

Floch, H. \& Abonnec, E., 1946, Simulidés de la Guyane Française (I). Inst. Pasteur Guyane et Terr. Inini, 136: 8.

Gedoelst, L., 1911., Synopsis de Parasitologie de l'Homme et des Animaux domestiques, $\mathrm{XX}+332$ pp., 327 figs., Bruxelles.

Lane, J. \& Porto, C. E., 1939, Simulideos da Região Neotrópica. Bol. Biol., S. Paulo, 4: 168-176.

Lane, J. \& Vulcano, M.A., 1943, A armadura bucal dos Simuliideos e seu valor taxonômico (Diptera, Simulidae). Rev. Ent., Rio de Janeiro, 14: 430-440.

Lutz, A., 1910, Segunda contribuição para o conhecimento das espécies brasileiras do gênero "Simulium". Mem. Inst. Oswaldo Cruz, 2: 213-267.

LUtz, A., 1922, Zoologia Médica. Folha Med., Rio de Janeiro, 3: 89-92.

Lutz, A. \& Machado, A., 1915, Viajem pelo rio S. Francisco e por alguns dos seus afluentes entre Pirapora e Joazeiro. Mem. Inst. Oswaldo Cruz, 7: $5-50$.

Neiva, A. \& Penna, B., 1916, Viajem científica pelo Norte da Bahia, sudoeste de Pernambuco, Sul do Piauí e de norte a sul de Goiás. Mem Inst. Oswaldo Cruz, 8: 74-224.

Patton, W.C. \& CRAGG, F.W., 1913, A Textbook of Medical Entomology, XI + 764 pp., Christian Lit. Soc. for India, London.

Prnto, C., 1930, Tratado de Parasitologia. Parasitos e Transmissores de Doenças. 2. ${ }^{a}$ parte, pp. 397-845, pls. 6-36, figs. 191-356, Pimenta de Melo \& Cia., Rio de Janeiro.

Pinto, C., 1931, Simuliidae da America Central e do Sul. 7. ${ }^{a}$ Reun. Soc. Arg. Patol. Reg. Norte: 661-763.

Pinto, C., 1938, Zoo-Parasitos de Interesse Medico e Veterinario. VIII + 376 pp., 105 pls., 162 figs., Pimenta de Mello \& Cia., Rio de Janeiro (cf. est. 48, fig. 8). 
Smart, J., 1945, The classification of the Simuliidae (Dipt.). Trans. R. Ent. Soc. London, 95: 463-532.

Surcouf, J. M. R. \& Gonzalez Rincones, R., 1911, Essai sur les Diptères Vulnerants du Venezuela, $320 \mathrm{pp}$.

Vargas, L., 1945, Simulidos del Nuevo Mundo. Inst. Salubr. Enf. Trop. Mex. Monograf. 1: 1-245, $10 \mathrm{pls}$.

VARGAS, L. \& NAJERA, A.D., 1951, Notas sobre sistematica y morfologica de Simulidos. Rev. Soc. Mex. Hist. Natur., 123-172, 77 figs.

Wilhelmi, J., 1920, Die Kriebelmückenplage. 246 pp., Jena. 
ESTAMPA 1

Simulium pruinosum Lutz

Fot. 1 - Canal de descarga, local onde a velocidade da água atinge a $3 \mathrm{~m}$ por segundo.

Fot. 2 - Fechamento da comporta do canal de descarga.

Fot. 3 - Turbilhão dágua, no momento de ser lançada para 0 antigo rio Pinheiros.

Fot. 4 - Parede de táboa entre os canais 1 e 2 . Notam-se as frinchas entre as táboas: "água chorada".

Fot. 5 - Tanques de decantação da água do D.A.E.

Fot. 6 - Detalhe da parede, forrada de pupas, larvas e ovos. 

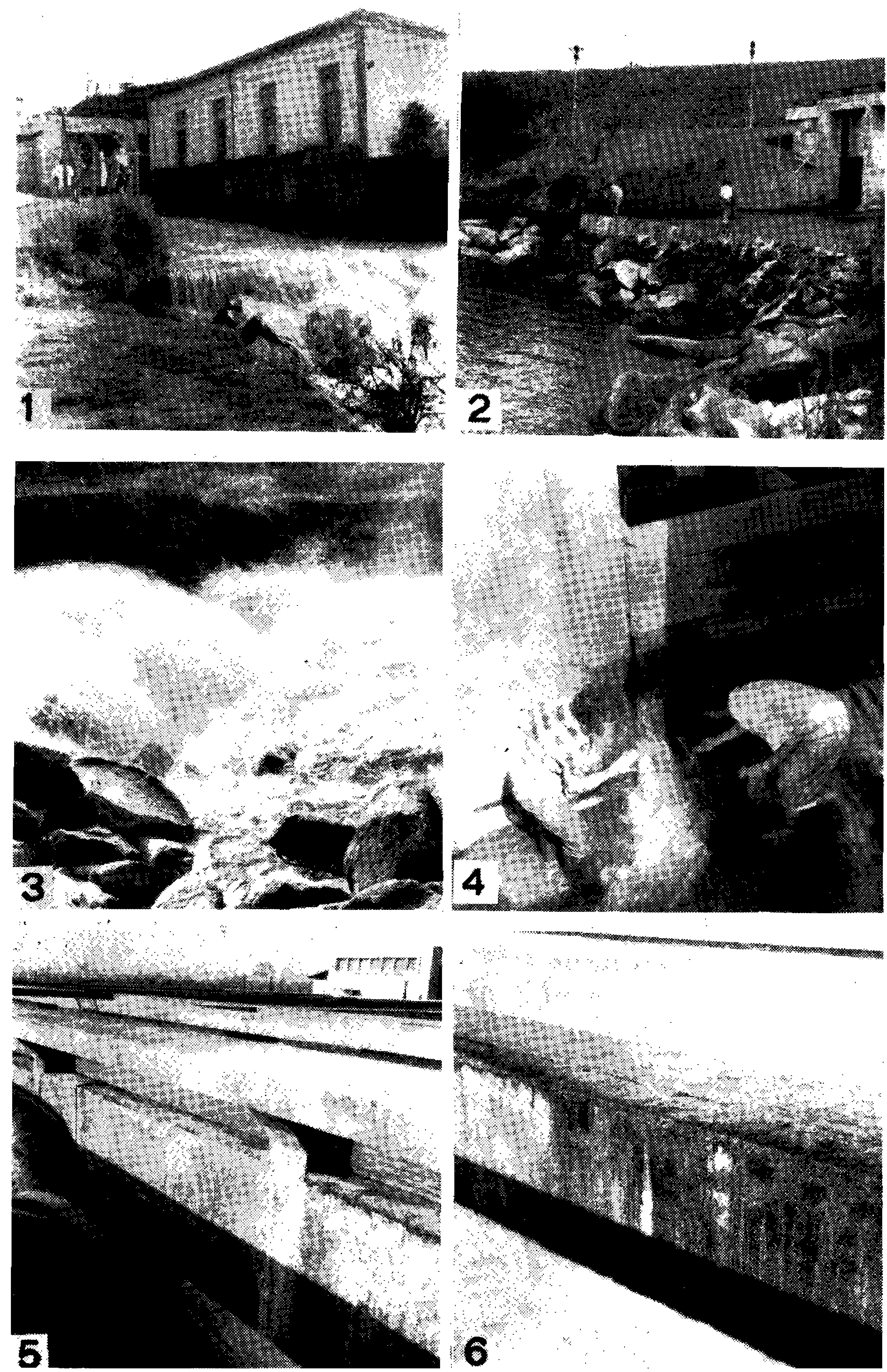

Vulcano: Alótipo de Simulium pruinosum 


\section{ESTAMPA 2}

\section{Simulium pruinosum Lutz, fêmea}

Fig. 1 - Área ocular frontal.

Fig. 2 - Antena

Fig. 3 - Palpo maxilar.

Fig. 4 - Extremidade distal da mandíbula.

Fig. 5 - Detalhe da borda externa da mandíbula com dois dentes.

Fig. 6 - Detalhe da borda externa da mandíbula com três dentes.

Fig. 7 - Extremidade distal da maxila.

Fig. 8 - Extremidade distal do labro-epifaringe.

Fig. 9 - Hipofaringe, armadura bucal.

Figs. 10 a 13 - Armadura bucal, processo mediano.

Fig. 14 - Extremidade distal da hipofaringe.

Fig. 15 - Lábio, lado direito.

As figuras $1,8,14$ e $15 ; 2$ e $3 ; 4,5$ e $6 ; 10,11,12$ e 13 respectivamente na mesma escala. 

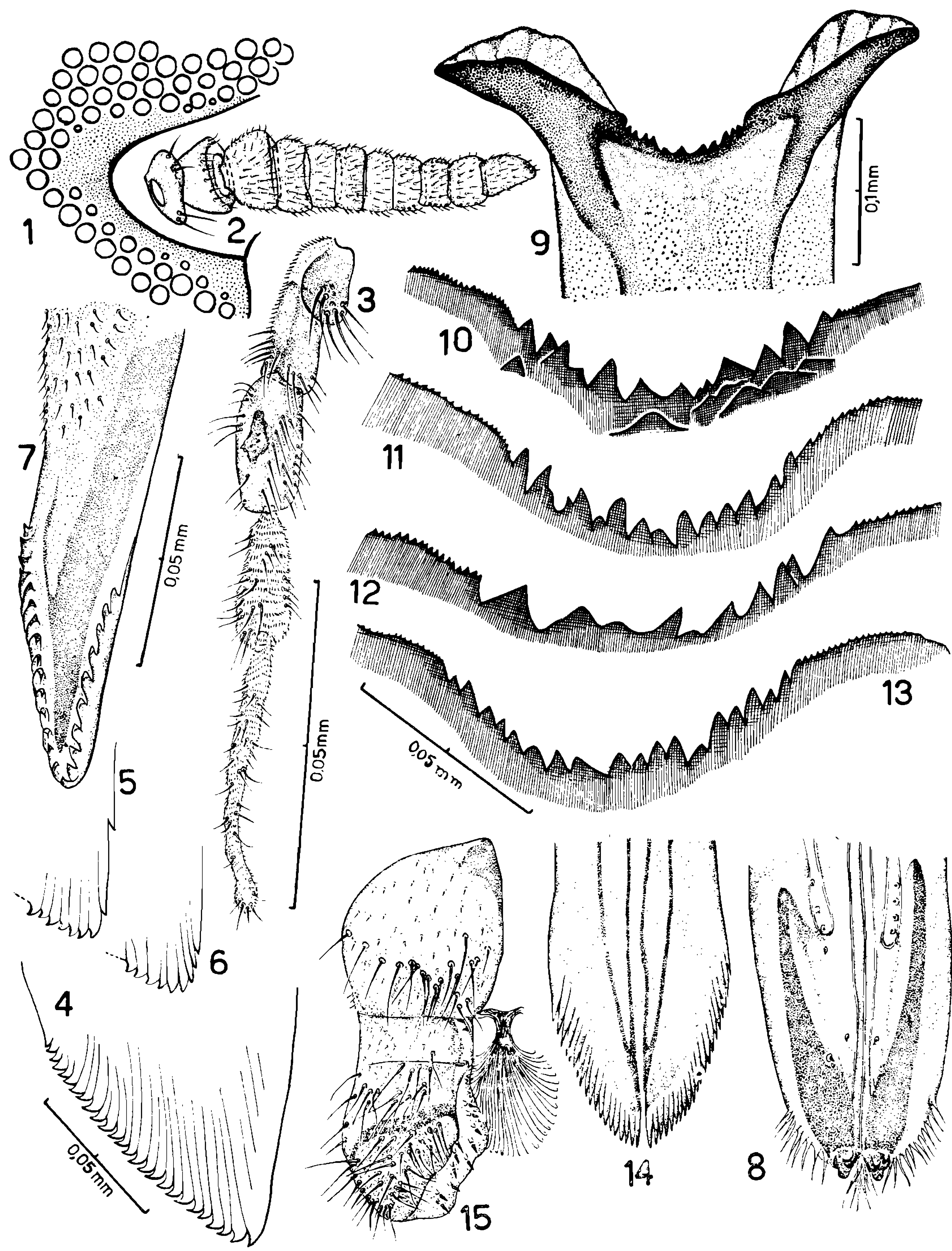

VUlCANo: Alótipo de Simulium pruinosum 
ESTAMPA 3

Simulium pruinosum Lutz, fêmea

Fig. 16 - Base da asa.

Fig. 17 - Perna anterior.

Fig. 18 - Perna media.

Fig. 19 - Perna posterior.

Fig. 20 - Calcípala e pedissulco.

Fig. 21 - Garra da perna anterior.

Fig. 22 - Gonapófise anterior direita, vista ventral.

Fig. 23 - Paraproctos e cercas.

Fig. 24 - Forquilha genital.

As figuras 16, 17, 18 e 19; 22, 23 e 24 respectivamente na mesma escala. 
Mem. Inst. Oswaldo Cruz,

57(1): 33-44 - Out., 1959

EST'AMPA 3

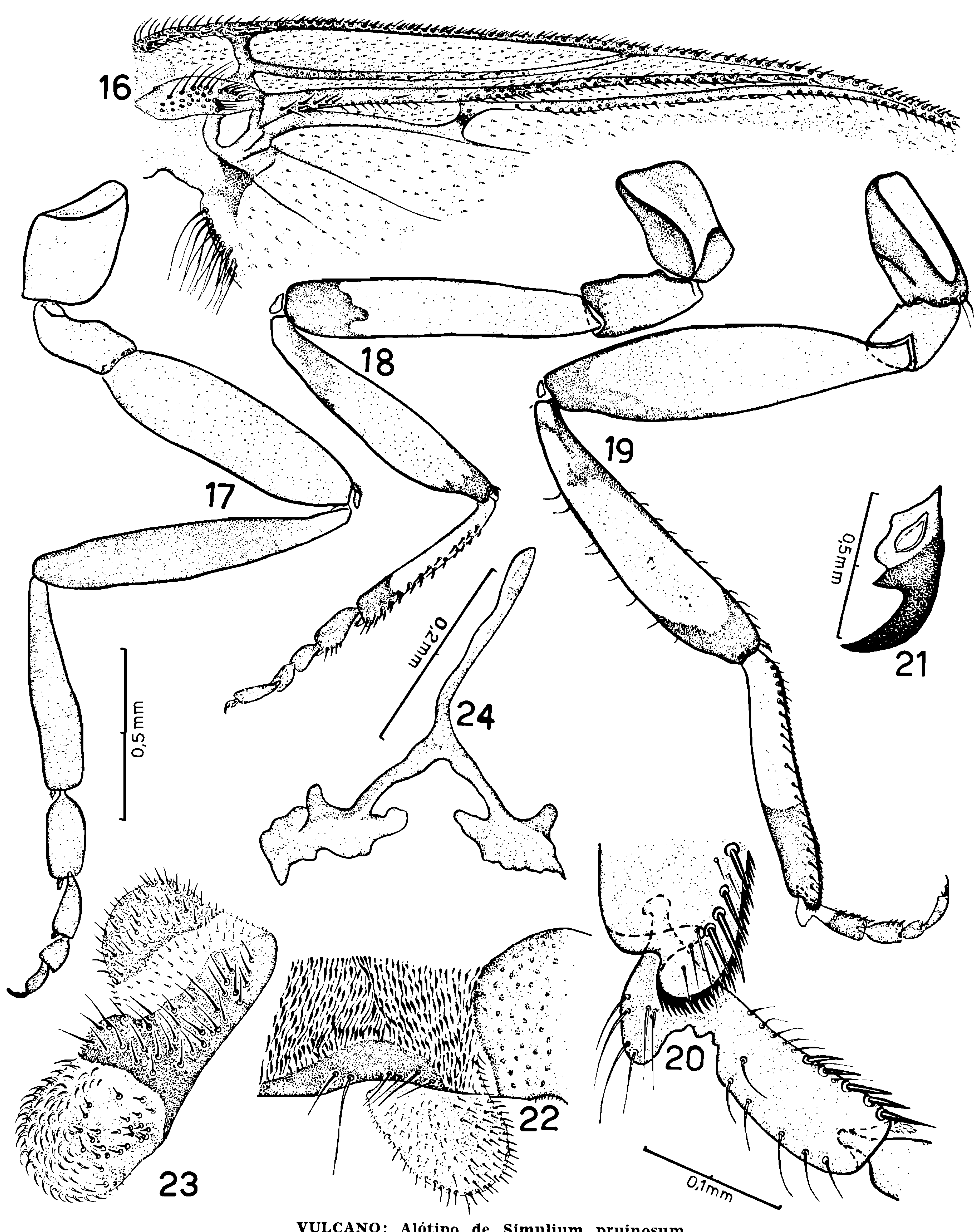

VULCANo: Alótipo de Simulium pruinosum 


\section{ESTAMPA 4}

Simulium pruinosum Lutz, macho

Figs. 25 e 26 - Antena.

Fig. 27 - Palpo maxilar.

Fig. 28 - Maxila.

Fig. 28a - Detalhe do árice da maxila.

Fig. 29 - Mandíbula.

Figs. 30 e 31 - Extremidade distal do labro-epifaringe.

Fig. 32 - Hipofaringe, armadura bucal.

Fig. 33 - Lábio direito.

Fig. 34 - Pinça, vista ventral.

Fig. 35 - Ápice da pinça direita do $10^{\circ}$ exemplar.

Fig. 36 - Ápice da pinça esquerda do $10^{\circ}$ exemplar.

Fig. 37 - Ápice da pinça direita do $2 .^{\circ}$ exemplar.

Fig. 38 - Ãpice da pinça esquerda do $2 .^{\circ}$ exemplar.

Fig. 39 - Ápice da pinça direita.

Fig. 40 - Ápice dà pinça esquerda.

Fig. 41 - Ãpice da pinça direita.

Fig. 42 - Ápice da pinça esquerda.

Fig. 43 - Ápice da pinça direita.

Fig. 44 - Ápice da pinça esquerda.

Fig. 45 - Ápice da pinça direita.

Fig. 47 - Processo anterior do falosoma, vista ventral.

Fig. 48 - Processo posterior do falosoma.

Fig. 49 - Tergito $\mathrm{X}$ e cercas.

As figuras $25,26,33$ e $34 ; 27,28,29,47$ e $49 ; 30,31,32,35$ a 46 e 48 respectivamente na mesma escala. 

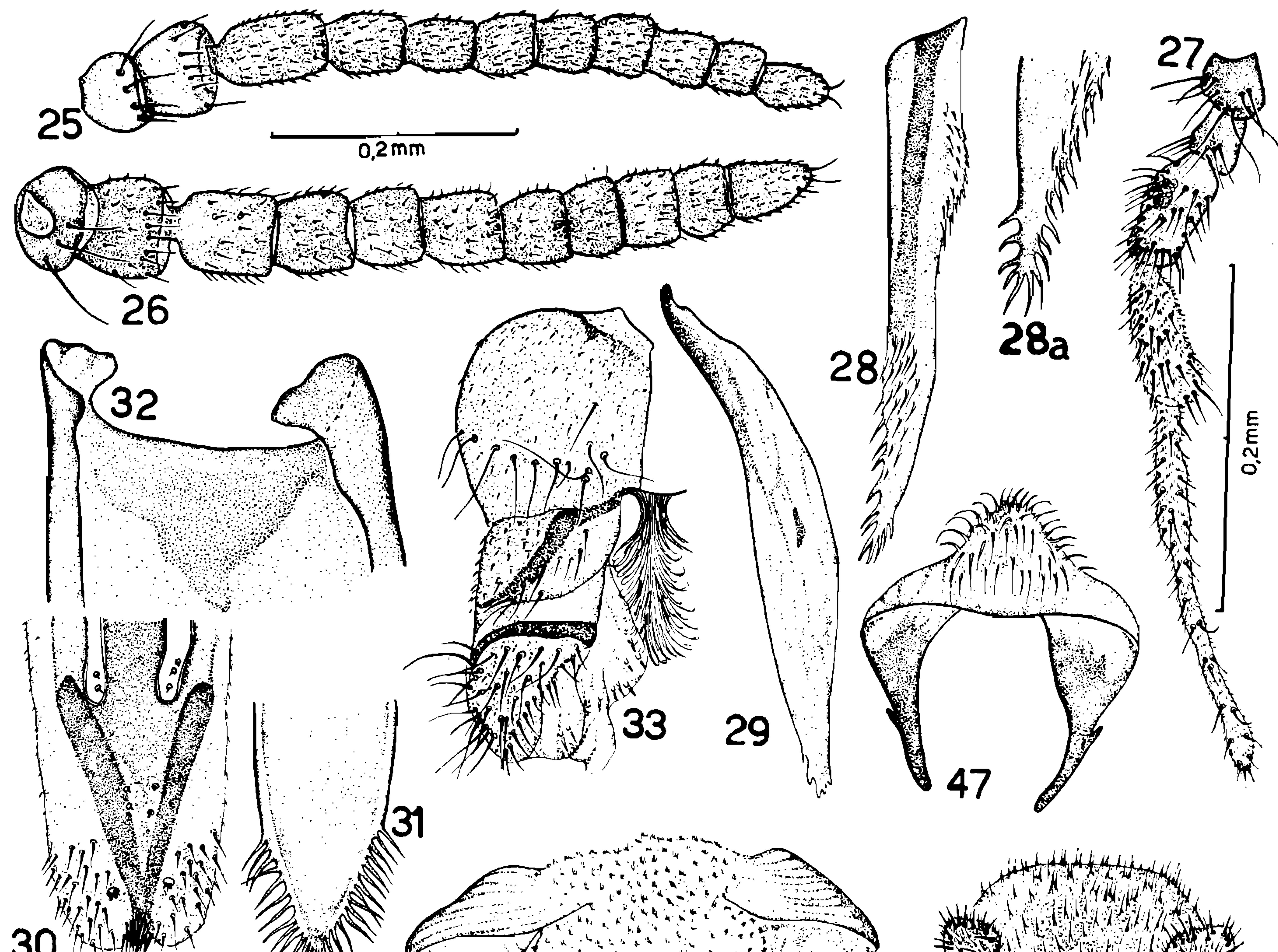

31
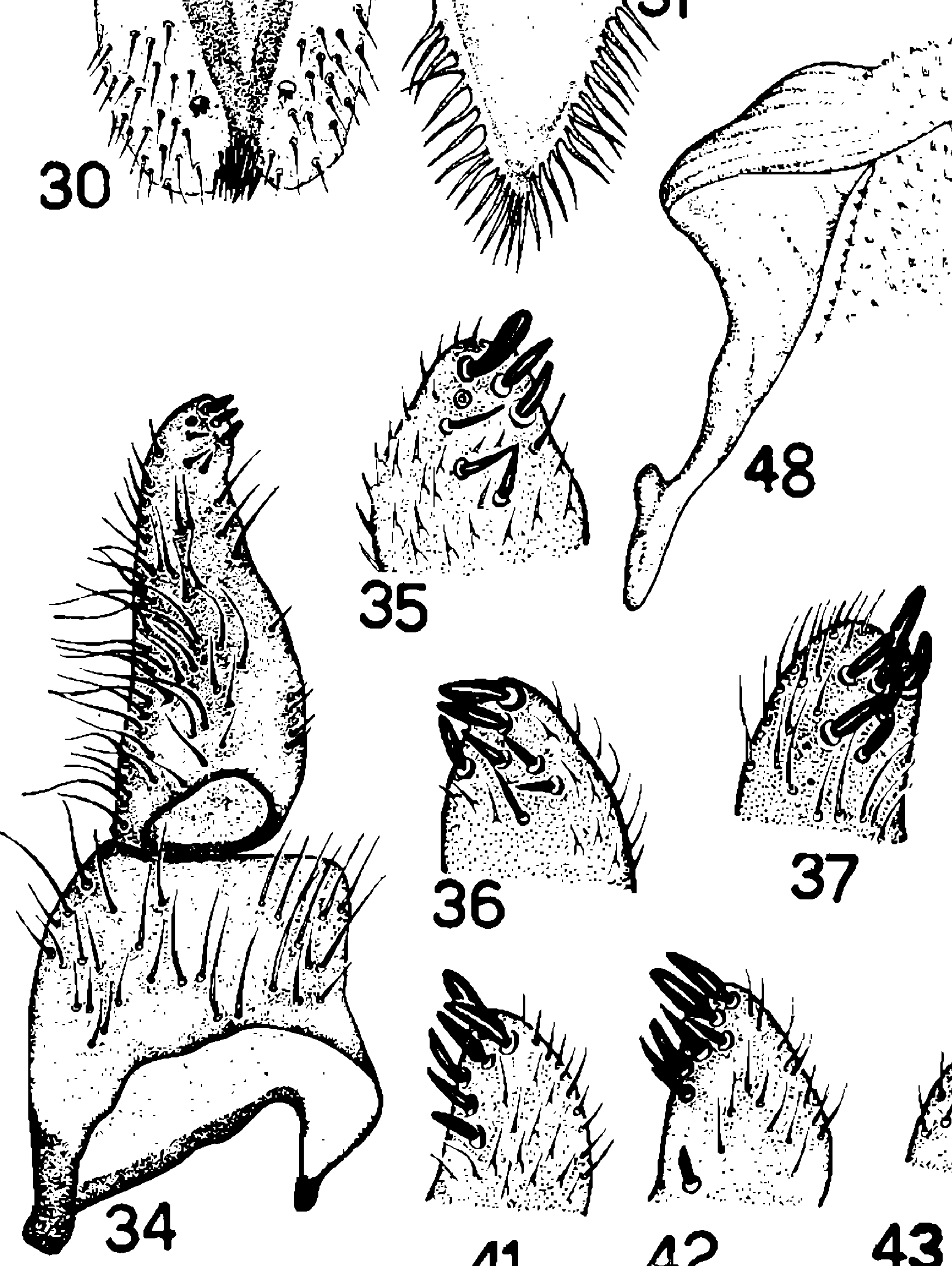

35

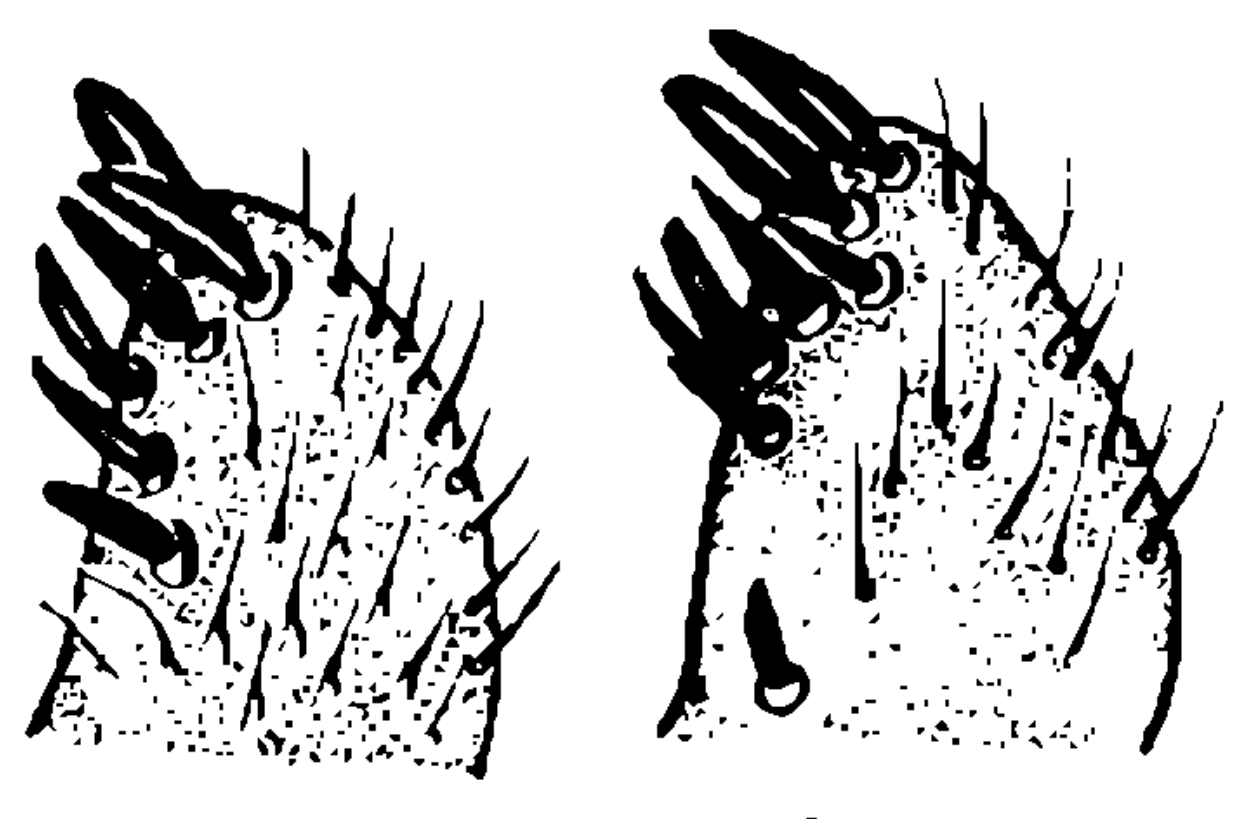

$41 \quad 42$

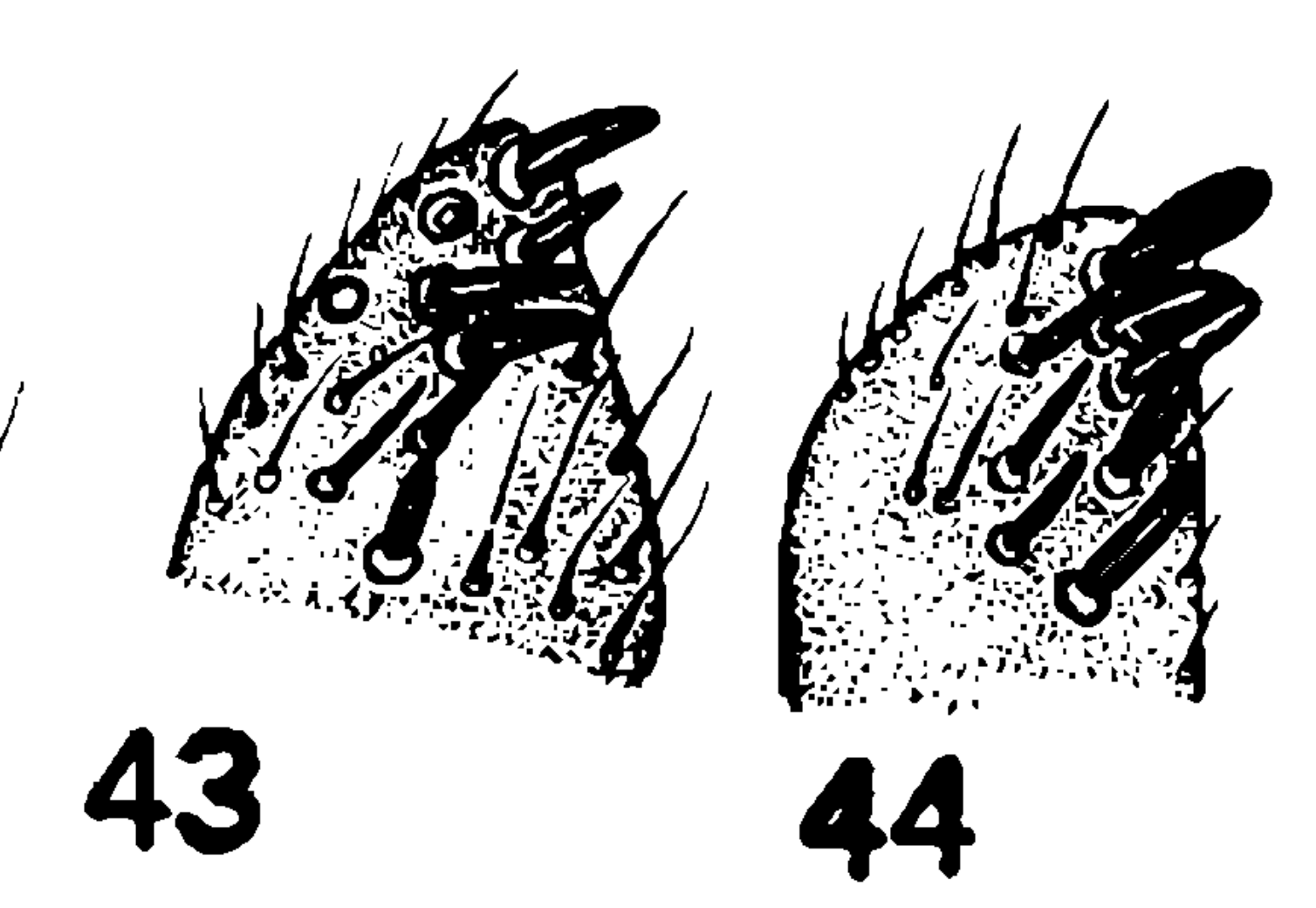

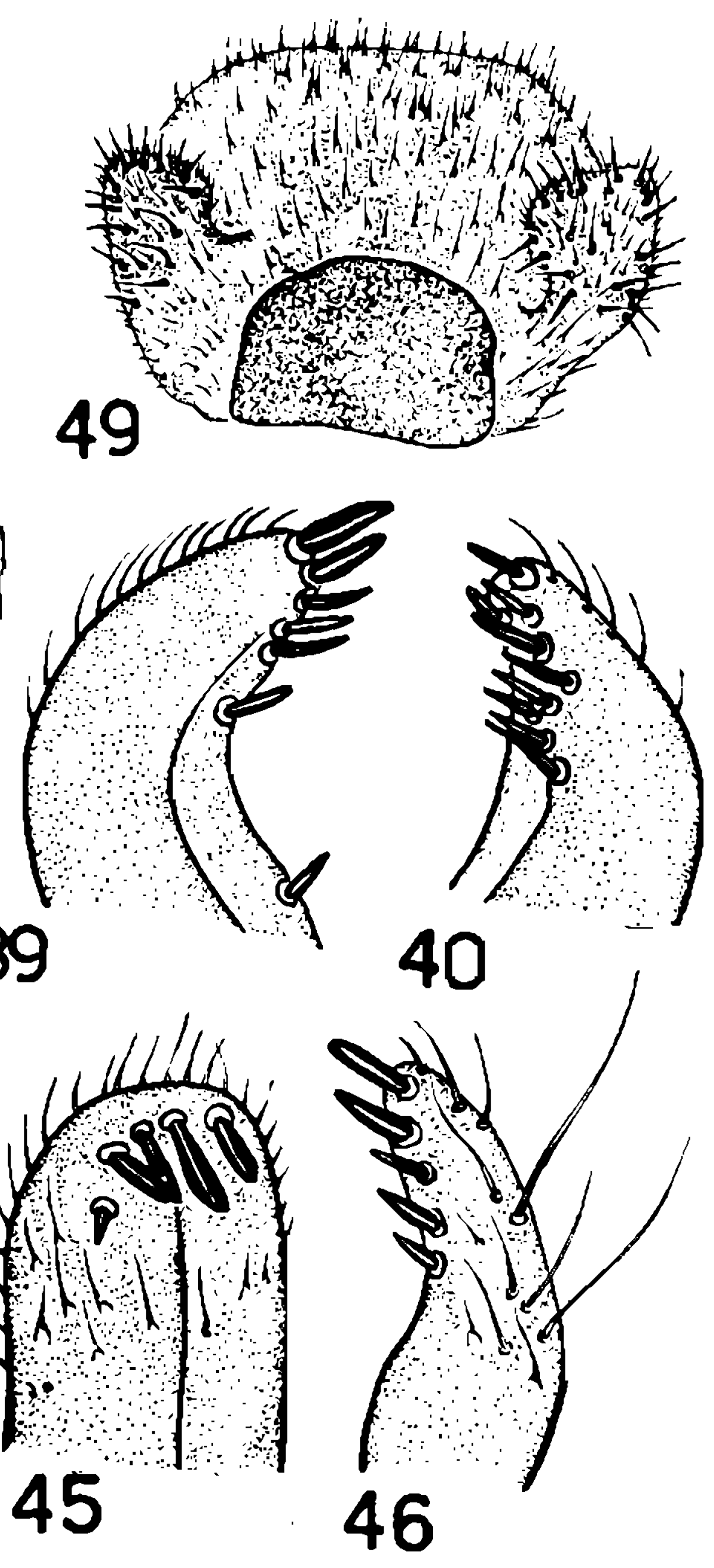

VUlCANo: Alótipo de Simulium pruinosum 
ESTAMPA 5

Fig. 50 - Pequena parte de uma colônia de larvas e pupas de $S$. pruinosum Lutz, 1910. Em uma planta delgada fixou-se uma pupa que serviu de sustentáculo a mais 8 pupas e 28 larvas, das quais foram removidas um certo número para execução do desenho. 
Mem. Inst. Oswaldo Cruz,

EST'AMPA 5

57(1): 33-44 - Out., 1959

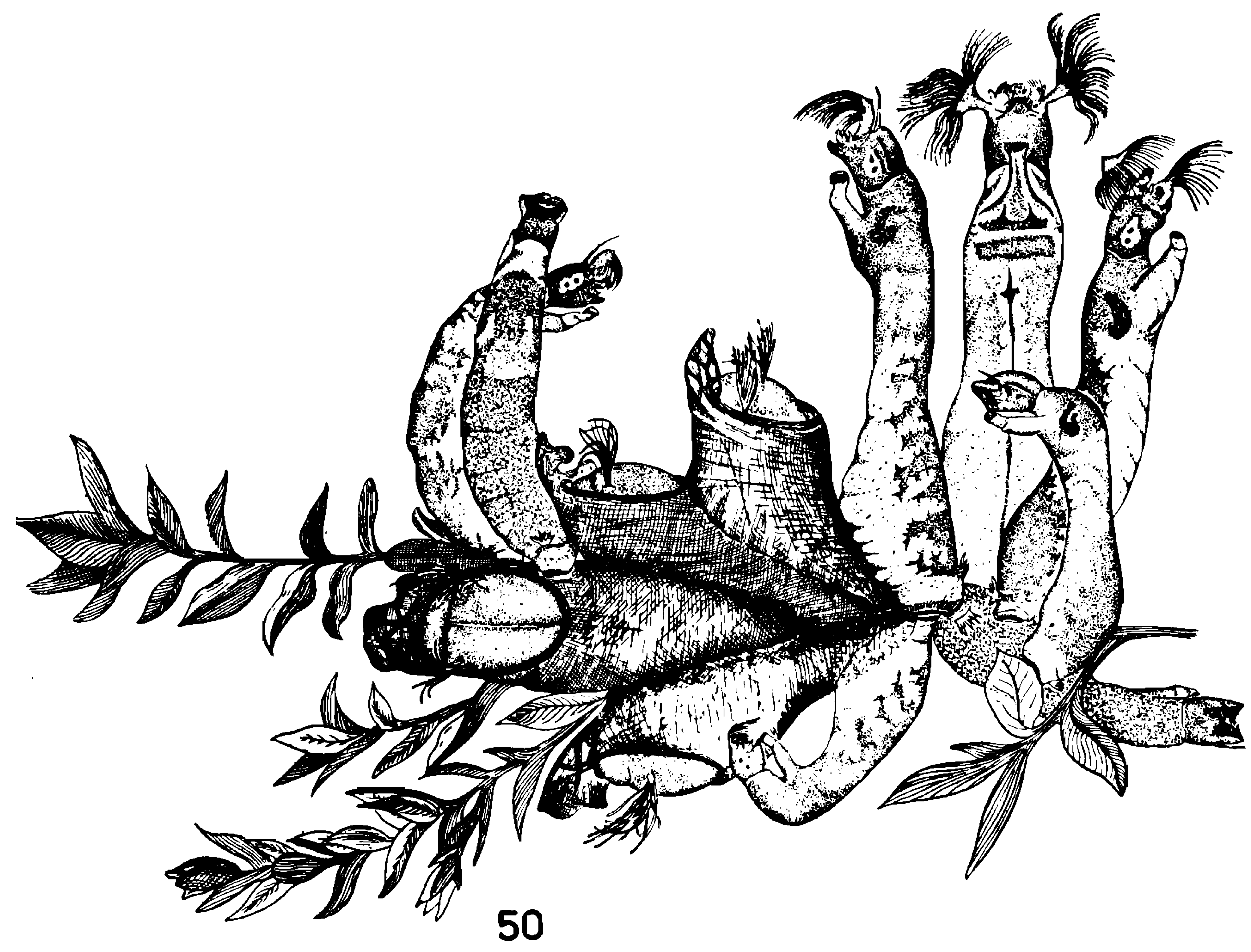

VULCANO: Alótipo de Simulium pruinosum 
ESTAMPA 6

Simulium pruinosum Lutz, pupa

Fig. 51 - Casulo, vista ventral.

Fig. 52 - Estojo cefálico, vista ventral.

Fig. 53 - Tricoma multiramificado da pele torácica.

Fig. 54 - Cerdas simples e bífidas da pele torácica.

Fig. 55 - Porção basal das brânquias respiratórias, mostrando a dicotomização.

Fig. 56 - Ramo anterior com dicótomo alto.

Fig. 57 - Ramo anterior com dicótomo baixo.

Fig. 58 - Ramo anterior mal desenvolvido.

Fig. 59 - Ramo anterior com esbôço de bifurcação.

Fig. 60 - Ramo anterior com a bifurcação nítida.

Fig. 61 - Extremidade das brânquias respiratórias em 4 exemplares.

As figuras 55, 56, 57, 58, 59 e 60 na mesma escala. 
Mem. Inst. Oswaldo Cruz,

57(1): 33-44 - Out., 1959

EST'AMPA 6

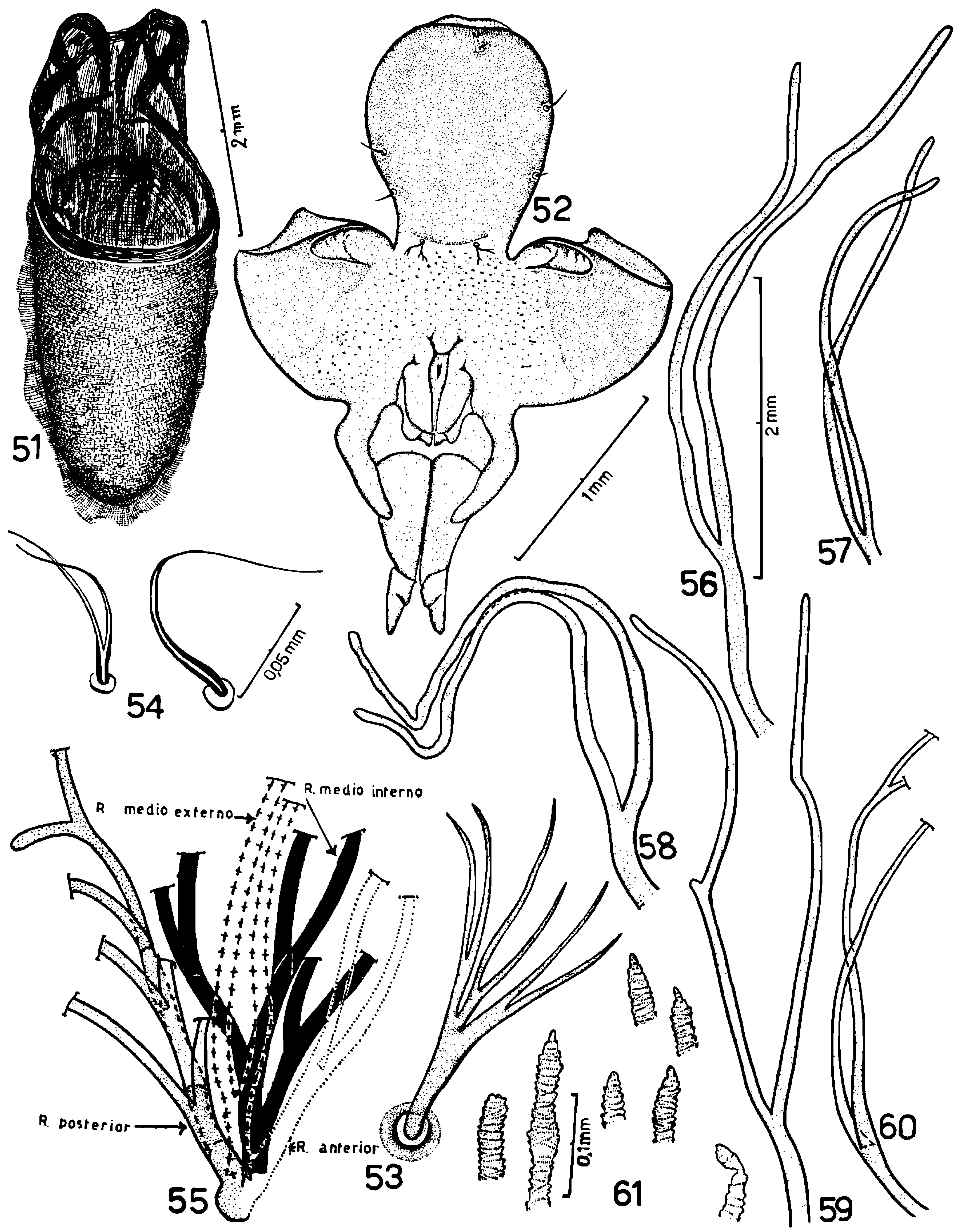

VUlCANo: Alótipo de Simulium pruinosum 


\section{ESTAMPA 7 \\ Simulium pruinosum Lutz, pupa}

Ramo médio interno, com variações na altura de dicotomização em um mesmo indivíduo; contando também os processos digitiformes.

Fig. 62 - Lado esquerdo com 6 ramificações.

Fig. 63 - Lado direito com 7 ramificações.

Fig. 64 - Lado esquerdo com 7 ramificações.

Fig. 65 - Lado direito com 6 ramificações.

Fig. 66 - Lado esquerdo com 7 ramificações.

Fig. 67 - Lado direito com 8 ramificações.

Fig. 68 - Lado esquerdo com 7 ramificações.

Fig. 69 - Lado direito com 7 ramificações.

Fig. 70 - Lado direito com 8 ramificações.

Fig. 71 - Lado esquerdo com 7 ramificações:

Fig. 72 - Lado esquerdo com 7 ramificações.

Fig. 73 - Lado direito com 7 ramificações

Fig. 74 - Lado esquerdo com 9 ramificações.

Fig. 75 - Lado direito com 6 ramificações.

Fig. 76 - Lado esquerdo com 9 ramificações.

Fig. 77 - Lado direito com 8 ramificações.

Fig. 78 - Lado esquerdo com 8 ramificações.

Fig. 79 - Lado direito com 8 ramificaçōes.

Fig. 80 - Lado esquerdo com 8 ramificaçōes (brânquias pequenas).

Fig. 81 - Lado direito com 9 ramificações (brânquias pequenas).

Fig. 82 - Lado direito com 8 ramificações (brânquias mal desenvolvidas).

Fig. 83 - Lado esquerdo com 8 ramificações (brânquias mal desenvolvidas).

Fig. 84 - Lado esquerdo com 8 ramificações.

Fig. 85 - Lado direito com 8 ramificações. 
Mem. Inst. Oswaldo Cruz,

EST'AMPA 7

57(1): 33-44 - Out., 1959

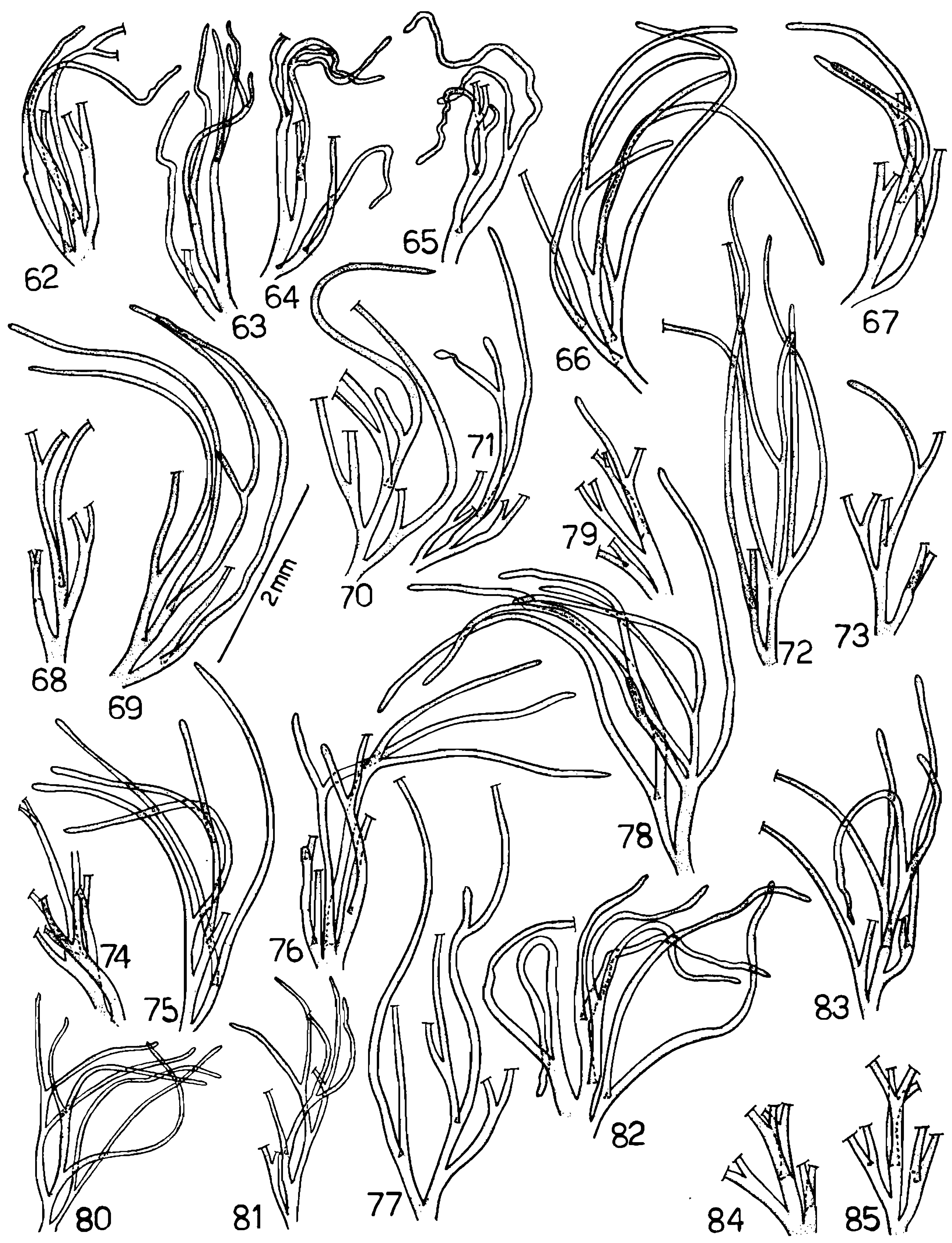

vulcano: Alótipo de Simulium pruinosum 
ESTAMPA 8

Simulium pruinosum Lutz, pupas

Ramo médio interno, com variações na altura de dicotomização em um mesmo indivíduo; contando também os processos digitiformes.

Fig. 86 - Lado direito com 8 ramificações (brânquias pequenas).

Fig. 87 - Lado esquerdo com 9 ramificações.

Fig. 88 - Lado direito com 7 ramificações.

Fig. 89 - Lado esquerdo com 8 ramificações.

Fig. 90 - Lado direito com 6 ramificações.

Fig. 91 - Lado direito com 8 ramificações.

Fig. 92 - Lado äireito com 7 ramificações.

Fig. 93 - Lado direito com 8 ramificações.

Fig. 94 - Lado direito com 7 ramificações.

Brânquia do lado esquerdo em diversos indivíduos:

Fig. 95 - Lado esquerdo com 8 ramificações.

Fig. 96 - Lado esquerdo com 8 ramificações.

Fig. 97 - Lado esquerdo com 7 ramificações.

Fig. 98 - Lado esquerdo com 8 ramificações.

Fig. 99 - Lado esquerdo com 8 ramificações. 
Mem. Inst. Oswaldo Cruz,

ESTAMPA 8

57(1): 33-44 - Out., 1959

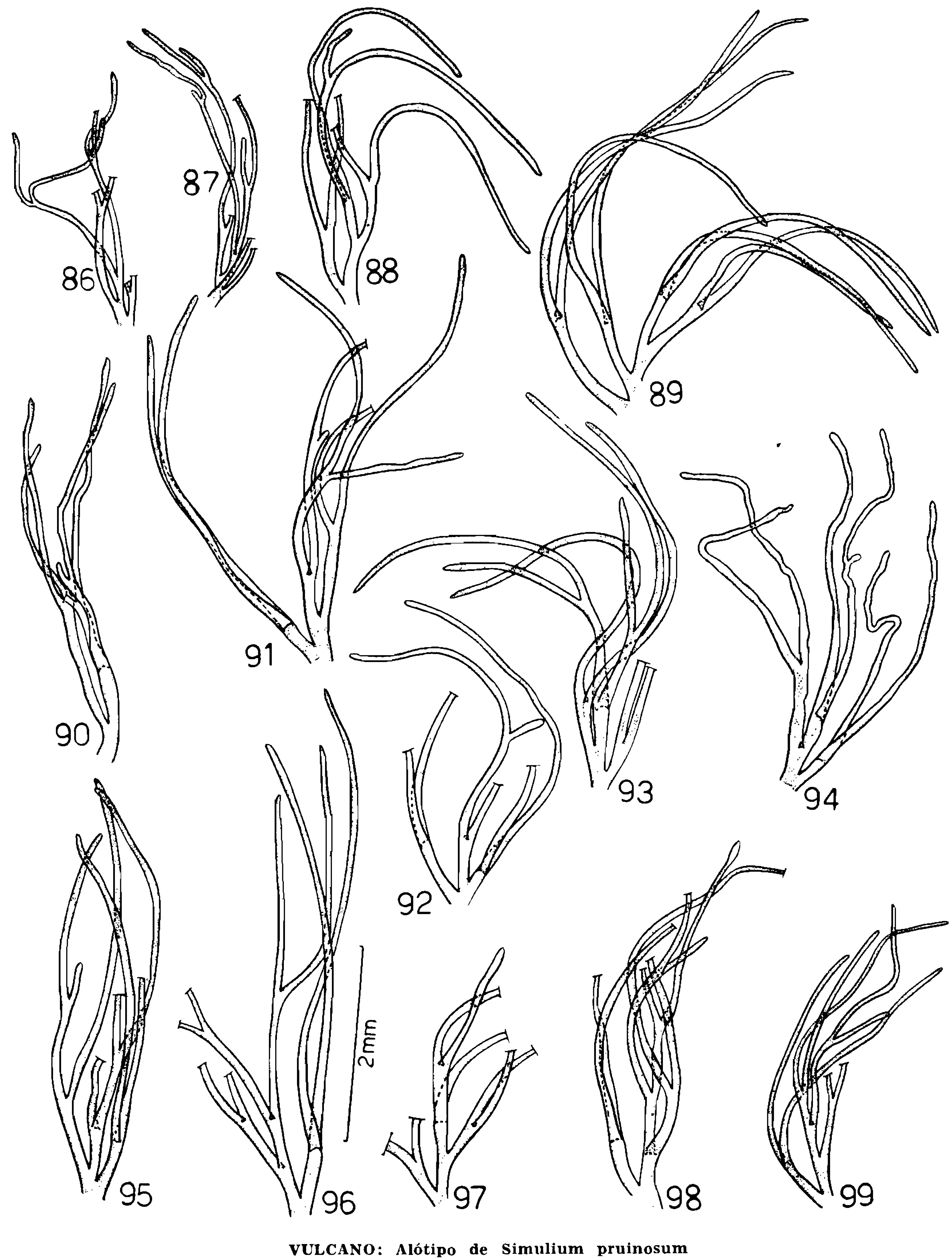




\section{ESTAMPA 9}

\section{Simulium pruinosum Lutz, pupa}

Ramo posterior com variação na altura de dicotomização em diversos indivíduos e em um mesmo indivíduo. Contando também os processos digitiformes.

Fig. 100 - Lado direito com 8 ramificações.

Fig. 101 - Lado direito com 6 ramificações.

Fig. 102 - Lado esquerdo com 6 ramificações.

Fig. 103 - Lado esquerdo com 6 ramificações.

Fig. 104 - Lado esquerdo com 8 ramificações.

Fig. 105 - Lado direito com 8 ramificações.

Fig. 106 - Lado esquerdo com 8 ramificações.

Fig. 107 - Lado direito com 7 ramificações.

Fig. 108 - Lado esquerdo com 8 ramificações.

Fig. 109 - Lado direito com 8 ramificações. 
Mem. Inst. Oswaldo Cruz

57(1): 33-44 — Out., 1959

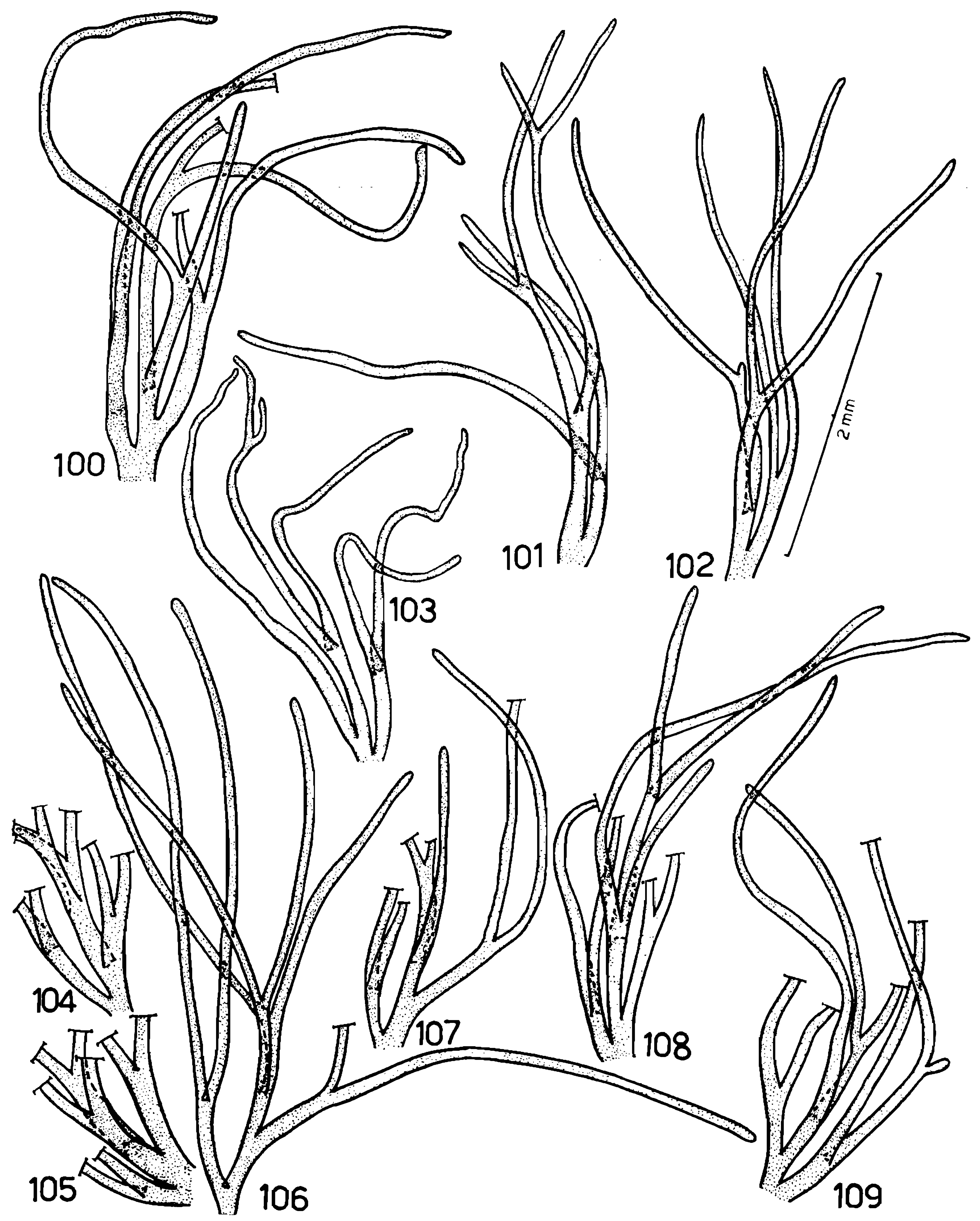

VUlCANo: Alótipo de Simulium pruinosum 
ESTAMPA 10

Simulium pruinosum Lutz, larva

Fig. 110 - Antena.

Fig. 111 - Escôva cefálica.

Fig. 112 - Mandíbula.

Fig. 113 - Dentes do ângulo supra interno da mandíbula.

Fig. 114 - Palpo maxilar e maxila.

Fig. 115 - Mento.

Fig. 116 - Borda superior do mento com os seus 10 dentes.

Fig. 117 - Brânquias anais com os 3 grupos, 2 laterais e uma posterior com as suas múltiplas ramificações.

As figuras $110,113,114$ e 116 na mesma escala. 


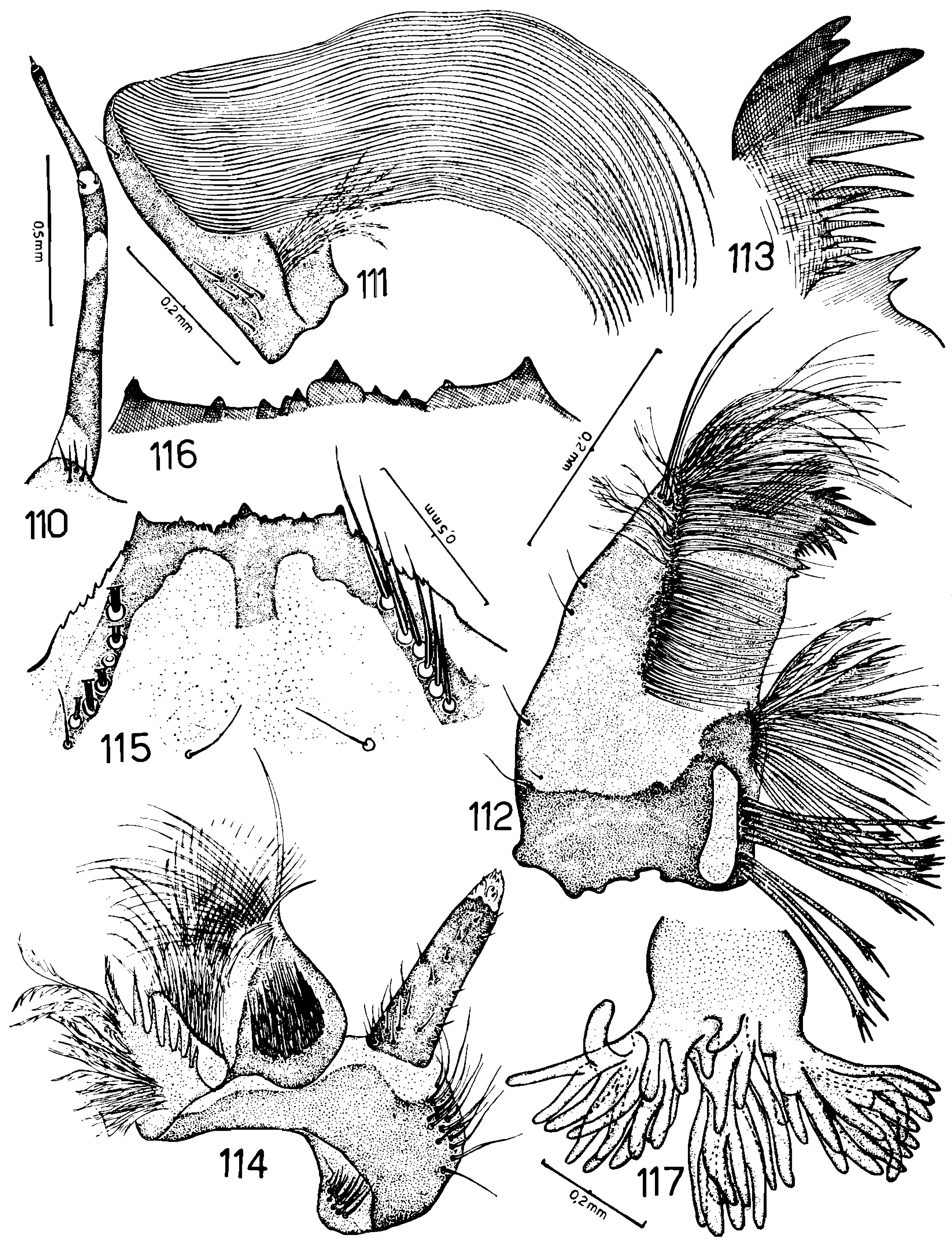

Vulcano: Alótipo de Simulium pruinosum 